UDC $330.88 / 339.9$

DOI 10.33111/iep.2020.32_33.02_eng

\title{
Development of the Platform Economy in the Global Digital Environment
}

\author{
OLHA LUKIANENKO ${ }^{1}$, \\ ANNA NIAMESHCHUK ${ }^{2}$
}

\begin{abstract}
The phenomenon of a platform economy formation is investigated in the paper, and a methodological format of identification of its key concepts is offered - platform product, platform project, platform investments, platform technologies, platform business, platform competition, platform thinking. The essential characteristics of platforms in technological and operational concepts have been given and the key trend of their transformation into an organizational base for formation of innovative micro- and macroecosystems has been confirmed. The platforms have been systematized by industry segmentation, nature of origin, user interaction, dominant technology, stage of the life cycle, owners, profitability and scale of operation. Particular emphasis is given to digital platforms, on the one hand, as to a product of the evolution of firms, and on the other hand, as to a product of global informatization and digitalization. The activity of platform development in terms of regions of the world and individual country-leaders has been analyzed. The concentration of platform business to the scale of individual cities or clusters has been determined. The conditions and factors of formation of platform business models and platform companies have been revealed. The gradual organization around the platform company of the innovation environment has been identified, which can be presented as a set of innovative "waves" of users with different degrees of modification and ways of using the basic technologies of the platform. The mechanism of interaction between users, developers and owners of platforms of different types has been revealed and sectoral features of their functioning have been shown. The growth of the global positive effect of platform innovations has been demonstrated as each subsequent "wave" of users being formed on the basis of aggregation of personal compliance of the platform product and multiplicative use of assets. Emphasis is given on the urgency of regulation of the interests of platform business participants in terms of their growing interdependence, in accordance with the policy of structured profit and the principle of protection of intellectual property rights. The fundamental architecture of platforms with emphasizing and analysis of its components and functional modules has been developed. The need to harmonize the "basic" functions and "peripheral" components of the platform, interacting on a systemic basis, with the parameters of demand in the markets of platform products to ensure the differentiation of relationships between participants, has been stated. Particular emphasis has been given to the assessment of non-financial effects in platform business models (including cumulative and compatibility or cross-platform), which arise in the process of role optimization and affect users' propensity to migrate between platforms, generation of competitive advantages of inter-platform competition. The prospects of the platform economy and relevant business ecosystems have
\end{abstract}

* This article was translated from its original in Ukrainian.

${ }^{1}$ Lukianenko Olha Dmytrivna - Doctor of Economics, Associate Professor, Professor at the Department of International Management of Kyiv National Economic University named after Vadym Hetman. Sphere of scientific interest: creative management, innovation, intellectual capital, digital economy. E-mail: Lukolga555@gmail.com

2 Niameshchuk Anna Valeriivna - Ph.D. (Economics), Associate Professor, Doctoral Student at the Department of International Management of Kyiv National Economic University named after Vadym Hetman. Sphere of scientific interest: intellectualization of global economy, management of global technological companies, digitalization of economy. E-mail: a.nyameshchuk@gmail.com

IEP, No. 32-33 (2020), pp. 26-48

(C) Olha Lukianenko, Anna Niameshchuk, 2020 «All rights reserved»

ISSN 1811-9832/2020/No. 1-2 (32-33) 
been substantiated, considering technological trends and socio-economic criteria of global development.

KEYWORDS: global digitalization, platform economy, digital platform, platform technologies, platform business models, platform companies, platform thinking, platform business ecosystem.

\section{Introduction}

Formation and rapid development of the platform economy in the first quarter of the XXI century are depend, on the one hand, on the processes of global informatization, networking, intellectualization and individualization, and on the other hand, on the evolution of firms, business models and regulatory practices in the new digital environment. The digital economy is becoming a key imperative of modern global development. According to experts, its growth rate is 2.5 times higher than global GDP growth, and the scale may reach USD 16 trillion in $2035^{3}$. Even today, the size of the digital economy is estimated to be from 4.5 to $15.5 \%$ of global GDP ${ }^{4}$. The drivers of these processes are digital platforms, which are beginning to play a leading innovative role in the global economy with unprecedented dynamics of their scaling. In 2017, the total value of companies operating on digital platforms exceeded USD 7 trillion, which is $67 \%$ more than in $2015 .^{5}$ The revolutionary nature of the digital transformation of business and society and their dynamic platforming have led to the acute relevance of interdisciplinary research on these phenomena by foreign and domestic scientists with extremely high publishing activity. Today it is possible to state the formation of a sufficiently holistic concept of platforms with a constantly updated conceptual apparatus. At the same time, a comprehensive analysis of conditions, factors and new features of platforming of global economy, relevant methodological conceptual identification, rethinking of criteria and features of systematization of platforms, first of all digital ones, generalization of implementation practices in various areas of platform models and assessment of platform economy prospects are necessary.

The aim of the article is to increase insight into the systematic interdisciplinary research of the phenomenon of formation of the

3 Khaustov, V. Digital Economy: How Do You Serve? (rus. Tsifrovava ekonomika: kak tebe sluzhitsya?). ZN.UA. 2019, No. 39. URL: https://zn.ua/macrolevel/cifrovaya-ekonomika-kak-tebe-sluzhitsya-333086_html.[In Russian].

${ }^{4}$ Digital Economy Report 2019. Value Creation Benefits: Implications for Developing Countries (rus. Doklad o tsifrovoy ekonomike 2019. Sozdanie stoimosti poluchenie vyigod: posledstviva dlva razvivavuschihsva stran) / UN Overview, 2019, UNCTAD. - 16 p. URL: https:/unctad.org/en/PublicationsLibrary/der2019_overview_ru.pdf. [In Russian]. - p. 5 .

5 Ibid, p. 8 . 
platform economy, the implementation of the latest achievements of digital transformations of business and society in the academic environment.

\section{Methodological format of platform economics research}

Academic identification of the concept of "platform" (Fig. 1) appeared in the scientific literature as a result of research on this phenomenon in the 1990s, in the concept of product platforms. The platform product was created on the basis of careful production and sales planning, each of which provides fundamental improvements in quality and productivity compared to the previous one ${ }^{6}$.

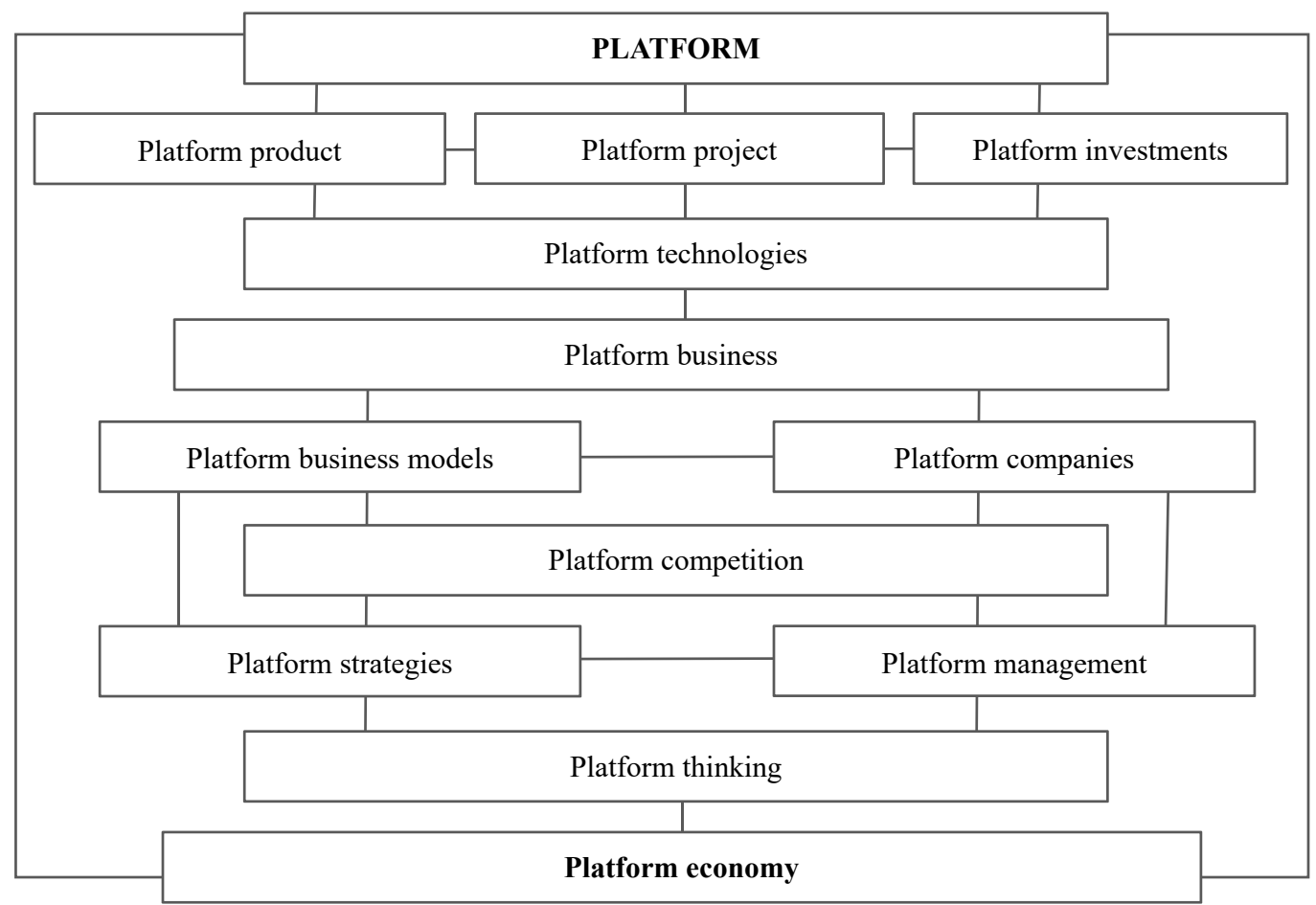

Fig. 1. Methodological format of identification of platform economy concepts

${ }^{6}$ Wheelwright S. C. \& Clark K. B. Creating Project Plans to Focus Product Development. Harvard Business Review. From the March-April 1992. Issue 70. URL: https://hbr.org/1992/03/creating-project-plans-to-focusproduct-development 
Deloitte Consulting interprets the product platform as transformation of product into a foundation for the development of other products; creation of framework that will encourage third parties to develop and sell a growing number of product variants ${ }^{7}$. This approach allows to consider the needs of consumers, differentiated by changing preferences, due to the offer of an extremely variable product on the market. For manufacturers, the competitive advantages of the platform product are due to the rapid launch of specialized products with less investment, due to modularity and flexibility, on the market. Transformation of a product into a product platform, according to Deloitte Consulting, means shifting the focus of intellectual property from just protection of its objects to balancing the interests of a group of producers within the innovation ecosystem.

Researchers also highlight the concept of a platform project that is developed to create a new generation or family of products for a particular company ${ }^{8}$. Later, there are distinguished platform investments in theory and practice - investments into core competencies in specific technologies ${ }^{9}$ with a potentially larger number of applications, which significantly expanded market opportunities and created new values. Platform investments are also considered as a way to prevent systematic bias in the decisions of managers and financial analysts regarding the short-term nature of the return on investment valuation ${ }^{10}$. In this way, it was intended to shift the emphasis from the current use of resources to the creation of organizational opportunities with long-term return (the use of "windows of opportunity"). The main advantages of platform investments were recognized the following opportunities: operation in conditions of uncertainty, parallel implementation of several organizational lines (arcs), intellectual protection and the difficulty of imitation without access to previous products of the family.

Platform technologies began to be used in rapidly developing industries due to competitive innovative advantages with the possibility of rapid product modernization or diversification in related segments ${ }^{11}$. Examining the ways of diversification in such areas, the author pointed

\footnotetext{
7 Turn products into product platforms Providing a foundation for others to build upon. URL: https:/www2.deloitte.com/content/dam/insights/us/articles/disruptive-strategy-productplatforms/DUP_3056_Products-to-platforms_v2.pdf

${ }^{8}$ Wheelwright S. C. \& Clark K. B. Creating Project Plans to Focus Product Development. Harvard Business Review. From the March-April 1992. Issue 70. URL: https://hbr.org/1992/03/creating-project-plans-to-focusproduct-development

${ }^{9}$ Kogut B. \& Kulatilaka N. Options Thinking and Platform Investments: Investing in Opportunity. California Management Review. 1994. Vol. 36, No. 2. - pp. 52 -71. URL: https://www.researchgate.net/ publication/239066520_Options_Thinking_and_Platform_Investments_Investing_in_Opportunity

${ }^{10}$ Ibid.

${ }^{11}$ Kim D.-J. \& Kogut B. Technological Platforms and Diversification. Organization Science. 1996. Vol. 7, No. 3. URL: https://www0.gsb.columbia.edu/faculty/bkogut/files/1996_OrgSci_Kim_Kogut.pdf
} 
to the effectiveness of platform technologies in terms of use of experience of intellectual product creation.

In general, platform technologies are considered to be the main technological trajectory of the company, which allows the transfer of generated knowledge to the development or generation of new markets.

In the technological (industry) concept, platforms are defined as organizational centers of change for adaptation or modernization of existing technologies with the systematic creation of new products, such as the computer market, where consumers are finally distributed among a small number of existing platforms, and their development is ensured by the modernization of existing generations of products ${ }^{12}$. A group of platforms means the creation of "service" platforms around the "main" platform. ${ }^{13}$ Cross-platforms imply creation of an external "open" platform and an internal "closed" platform ${ }^{14}$.

The operational concept, primarily in the field of services, provides for the identification of transactional platforms as a means of assurance of rapid interaction of numerous participants ${ }^{15}$ with user segmentation ${ }^{16}$ in the case of a multilateral platform.

Since the 2000s, a new research trend has been the positioning of platforms as an organizational basis for the formation of innovative ecosystems, achievement of higher competitiveness and leadership. At the same time, leadership on the platform is based on the efforts of large companies to turn their business into a platform for building the businesses of other companies ${ }^{17}$. The architectural leadership of a platform is a combination of technological advantages with advantages in the business model for newly created platforms ("coring" strategy) and competing platforms ("tipping" strategy) ${ }^{18}$. External platforms act as a set of products, services and technologies developed by a small number of companies, which serves as a basis for the implementation of

\footnotetext{
12 Bresnahan, T.F. and Greenstein, S. Technological competition and the structure of the computer industry. Journal of Industrial Economics, 1999. 47 (1). - pp. 1-40. URL: http://www-siepr.stanford.edu/workp/ swp97028.pdf

${ }^{13}$ Baldwin, C. Y. and Woodard, C. J. The Architecture of Platforms: A Unified View / Platforms, Markets and Innovation. The Architecture of Platforms: 2009, Cheltenham, UK and Northampton, US: Edward Elgar. URL: https://www.elgaronline.com/view/9781848440708.xml

${ }^{14}$ Ibid.

15 Rochet, J.-Ch. ; Tirole, J. Platform Competition in Two-Sided Markets. Journal of the European Economic Association. 2003. T. 1, No. 4. - pp. 990-1029. URL: https://www.rchss.sinica.edu.tw/cibs/pdf/RochetTirole3.pdf

16 Hagiu, A. \& Wright, J. Multi-Sided Platforms. Harvard Business School March. 2015. URL: http://www.hbs.edu/faculty/Publication\%20Files/15-037_cb5afe51-6150-4be9-ace2-39c6a8ace6d4.pdf

17 Gawer, A. and Cusumano, M.A. Platform Leadership: How Intel, Microsoft, and Cisco Drive Industry Innovation, Boston, MA: Harvard Business School Press. 2002. URL: http://platformleadership.com/articles/ Case\%20Folio.pdf

18 Gawer, A. and Cusumano, M. A. Strategies for Platform-Leader. Wannabes 26 August 2007. URL: http://www.iips.org/publications/data/07techGawer.pdf
} 
appropriate complementary innovations for a large number of other companies $^{19}$.

Platform thinking, as a philosophy of modern marketing, is becoming relevant in an environment where consumers are becoming more demanding and require individualized products, and the cost of creation and marketing of such products is constantly growing and formation of a common logic may be effective for companies. It is interpreted as a strategic vision of the company in the process of development and offer of its products not as separate projects in the portfolio, but as the formation of a single logic for choosing the basic production technology. Platform thinking can be applied to products (product families), brands (brand systems), target consumer segments (related segments), market geography (global expansion) and business processes (organizational adaptation $)^{20}$.

At the macro level, the phenomenon of the formation of the platform economy of capitalism has been systematically studied by N. Srnychek, focusing on the transformation of firms into platforms in many sectors of the economy over the past forty years, the formation of platforms of various types, the development of competitive relations of new content and format ${ }^{21}$. At the micro level, the formation of digital platform business models was studied mainly by foreign scientists - Rochet J.-C., Tirole J. ${ }^{22}$, Armstrong M. ${ }^{23}$, Hagiu A. ${ }^{24}$, Rysman M. ${ }^{25}$, Antypina O. ${ }^{26}$.

In global business, platforms function as meta-organizations, i.e. developing organizations, combining competing innovators, they create

19 Gawer, A., Cusumano, M. A. Industry Platforms and Ecosystem Innovation. J Prod Innov Manag 31 September 4, 2013, No. 3. - pp. 417-433. URL: https://dspace.mit.edu/bitstream/handle/1721.1/98590/ Cusumano_Industry\%20platforms.pdf? sequence=1\&isAllowed=y.

${ }^{20}$ Sawhney, M. S. Leveraged High-Variety Strategies: From Portfolio Thinking to Platform Thinking. Journal of the Academy of Marketing Science. 1998. Vol. 26, No. 1. - pp. 54-61. URL: https://www.researchgate.net/ publication/226750238_Leveraged_High-Variety_Strategies_From_Portfolio_Thinking_to_Platform_Thinking.

${ }^{21}$ Srnychek N. Platform Capitalism (rus. Kapitalizm platform) [Text] / transl. from English and sc. ed. By M. Dobryakova; National Research University "Higher School of Economics" (rus. Nats. issled. un-t "Vyisshaya shkola ekonomiki"). Moscow: Ed. House of the Higher School of Economics, 2019. - 128 p. [In Russian].

${ }^{22}$ Rochet, J.-C., Tirole, J. Platform Competition in Two-Sided Markets. Journal of the European Economic Association. 2003, No. 1 (4). - pp. 990-1029. URL: https://www.rchss.sinica.edu.tw/cibs/pdf/RochetTirole3.pdf.; Rochet J.-C., Tirole J. Two-Sided Markets: a progress report. The RAND Journal of Economics. 2006, Vol. 37, No. 3. P. 645-667.

${ }_{23}$ Armstrong, M. Competition in Two-Sided Markets. The RAND Journal of Economics. 2006, Vol. 37, No. 3. pp. 668-691.

${ }^{24}$ Hagiu, A. Pricing and Commitment by Two-Sided Platforms. The RAND Journal of Economics. 2006 , Vol. 37, No. 3. - pp. 720-737.

${ }_{25}$ Rysman, M. The Economist of Two-Sided Markets. Journal of Economic Perspectives. 20069, Vol. 23, No. 3. - pp. 125-143.

${ }^{26}$ Antipina O. N. How much is a digit worth? On the nature of the price of goods in the digital economy (rus. Skolko stoit tsifra? O prirode tsenyi blag $\mathrm{v}$ tsifrovoy ekonomike). Social sciences and modernity (rus. Obschestvennyie nauki i sovremennost). 2019, No. 5. - pp. 5-16. [In Russian]. 
added value due to the effect of scale, form a technological architecture, which is built modularly on the principle of "core - periphery" ${ }^{27}$.

\section{Platforms in the modern economic landscape}

The evolution of companies in the information, primarily digital environment, has led to the appearance and rapid development of platforms. Active research initiates numerous approaches to their classification. One of the most common, in our opinion, is the identification of types of platforms that facilitate transactions, interaction and mobility: ${ }^{28}$

- aggregation platforms combine a large number of resources and help users connect to the right resources according to a logical chain "to show the need - to get an answer - to make a deal - to move on". All transactions in aggregation platforms are organized by the platform owner or authorized agent. Aggregation platforms are divided into the following categories: data and information collection; market and brokerage (provide a space for more comfortable interaction of suppliers with consumers regardless of location); competitive (they set out the problems to be solved with the indication of the performer's remuneration);

- social platforms bring together a large number of resources and users in order to build and strengthen, using various ways, long-term relationships in a wide range of interests, without the direct intervention of the platform owner or authorized agent. The following platforms are the most attractive: $15 \%$ of mobile time in the United States is spent on social media $^{29}$, and the average adult in the United States spends 42.1 minutes. per day for Facebook use, and 17.1 minutes for Twitter use;

- mobilization platforms - motivational communities that unite participants by interests on the basis of long-term relationships and motivate them to actions, the result of which is impossible without joint efforts. The resource of each participant of the platform is considered as static, and the function of the owner of the platform is to combine and use them as efficiently as possible.

27 Gawer A. Bridging differing perspectives on technological platforms: Toward an integrative framework. Research Policy. 2014, Vol. 43. - pp. 1239 - 1249 URL: https://reader.elsevier.com/reader/sd/pii/ S0048733314000456? token=E6A6AB71472790461F89059913D1BF85632768A200F34D88A02C53F602FBFEC4 E9990A5038925D1F3275DB04BEFB58FB.

${ }^{28}$ Hagel, J. The power of platforms. Part of the Business Trends series. Deloitte Development LLC. 2015. URL: https://www2.deloitte.com/us/en/insights/focus/business-trends/2015/platform-strategy-new-level-businesstrends.html.; Deloitte Development LLC. Patterns of disruption: anticipating disruptive strategies in a world of unicorns, black swans, and exponentials. Bratislava: Deloitte University Press. 2015. URL: https://www2.deloitte.com/content/dam/Deloitte/nl/Documents/technology/deloitte-nl-deloitte-patterns-ofdisruption.pdf.

${ }^{29}$ Leger, B. Fresh Mobile Trends. Upland Localytics. URL: http://info.localytics.com/blog/mobile-statistics. 
High dynamics is a characteristic of the process of formation and scaling of training platforms, which will allow platform owners to train users, increase their personal productivity, competence and skills based on trust, in order to fully unleash their potential in the course of teamwork ${ }^{30}$. In fact, within such a platform, "creation spaces" are formed - teams, small in number, aimed at ensuring productivity through trust relationship and access to implicit knowledge, which increases the potential for learning outside the team.

Both theoretical and practical interests are represented by the typology of platforms, which reflects the specifics of the behavior of platform business in the market ${ }^{31}$ :

- transactional platform - a product, technology or service that acts as a channel (or intermediary) between users of the platform to facilitate exchanges and transactions (e.g. Alibaba, Amazon, Uber, Airbnb, Baidu);

- innovative platform - a product, technology or service that serves as a basis for the innovation ecosystem for their own development of additional products, technologies or services by other companies with a less organized innovation system (e.g. Windows, Android, Salesforce);

- integrated platform - a product, technology or service that is both a transactional and an innovative platform (such as Apple);

- investment platform - platforms consisting of companies that pursue the strategy of the investment portfolio of platforms as a holding company and/or an active investor of the company.

The UN Digital Economy Report ${ }^{32}$ interprets operating platforms as bilateral or multilateral markets with online infrastructure that enable transactions between different parties. Innovative platforms are an environment in which code and content developers create applications and software in the form of operating systems or technology standards.

Today, almost all platforms operate in a digital environment. The driving force of the modern stage of informatization as a categorical imperative was the digital data as a result of scientific progress, on the

\footnotetext{
${ }^{30}$ Hagel, J. The power of platforms. Part of the Business Trends series. Deloitte Development LLC. 2015. URL: https://www2.deloitte.com/us/en/insights/focus/business-trends/2015/platform-strategy-new-level-business-trends.html.; Deloitte Development LLC. Patterns of disruption: anticipating disruptive strategies in a world of unicorns, black swans, and exponentials. Bratislava: Deloitte University Press. $2015 . \quad$ URL: https://www2.deloitte.com/content/dam/Deloitte/nl/Documents/technology/deloitte-nl-deloitte-patterns-of-disruption.pdf.

31 Evans, P. C., Gawer, A. The Rise of the Platform Enterprise: A Global Survey. The Center for Global Enterprise. 2016. URL: https://www.bearingpoint.com/files/Global Platform Survey Jan 2016.pdf\&download=

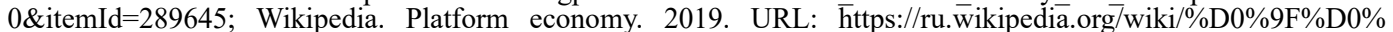

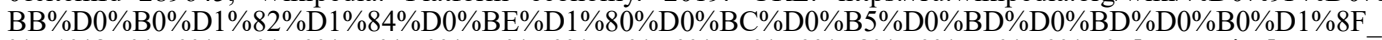
$\% \mathrm{D} 1 \% 8 \mathrm{D} \% \mathrm{D} 0 \% \mathrm{BA} \% \mathrm{D} 0 \% \mathrm{BE} \% \mathrm{D} 0 \% \mathrm{BD} \% \mathrm{D} 0 \% \mathrm{BE} \% \mathrm{D} 0 \% \mathrm{BC} \% \mathrm{D} 0 \% \mathrm{~B} 8 \% \mathrm{D} 0 \% \mathrm{BA} \% \mathrm{D} 0 \% \mathrm{~B} 0$. [In Russian].

32 Digital Economy Report 2019. Value Creation Benefits: Implications for Developing Countries (rus. Doklad o tsifrovoy ekonomike 2019. Sozdanie stoimosti poluchenie vyigod: posledstviya dlya razvivayuschihsya stran) / UN Overview, 2019, UNCTAD. - 16 p. URL: https://unctad.org/en/PublicationsLibrary/der2019_overview_ru.pdf. [In Russian]. - p. 3.
} 
one hand in mathematics, cryptography and game theory, and on the other hand in materials with the discovery of new properties, design and assembly tools. In recent years, the potential of computing, including cloud, quantum, optical, biological, neural, has been growing qualitatively. The digital economy is based on digital technologies, including digital business, digital regulation and digital infrastructure. Digital thinking is becoming predominant in it, and digital platforms, the formation of which had its own logic, are becoming the most adequate organizational form (Fig. 2).

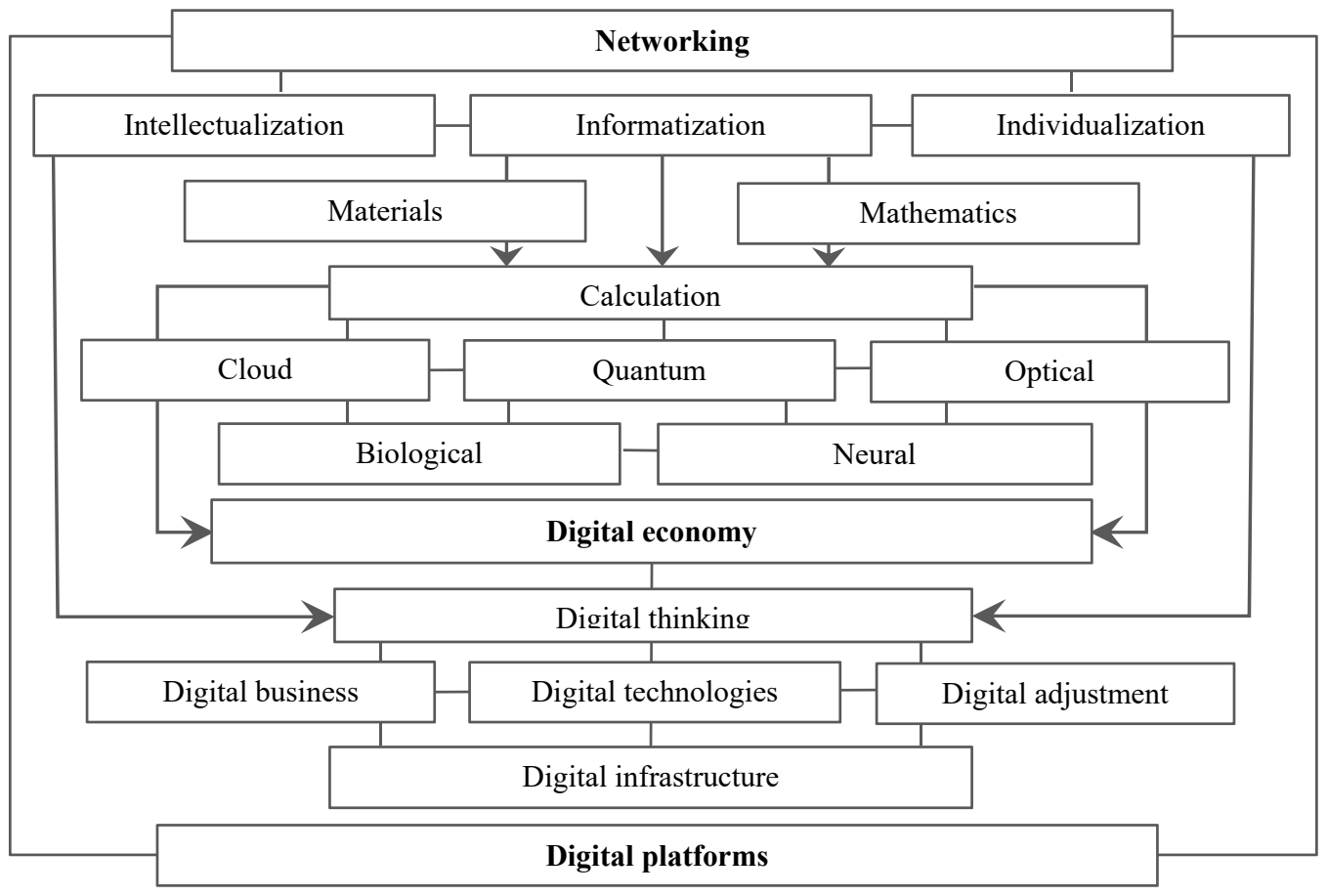

Fig. 2. Digital landscape of platform economy

Digital platforms act as intermediary infrastructure platforms with the ability to extract all data of online activity and user transactions, their registration and analysis. In a narrower sense, they provide the interaction of variables and determine business models based on digital data $^{33}$. That is, it is a mechanism that allows different parties to interact online.

${ }^{33}$ Oleinikova Yu.A. Challenges and business development models in the context of progress (rus. Vyizovyi i modeli razvitiya biznesa $\mathrm{v}$ usloviyah progressa). Innovative Economy Issues (rus. Voprosyi innovatsionnoy ekonomiki). 2019. No. 4. [In Russian]. - p. 1418. 
Users mean developers and consumers of products that can be provided online. Products that move from developers to consumers take the form of online services and information that can be transmitted almost instantly, or online images of physically existing products that are actually transmitted after platform interaction. In parallel with the exchange in the chain "developer - consumer" there is an exchange "developer - platform" and "consumer - platform". The subject of this exchange is an exceptionally intellectual product - an intellectual property object provided by the platform to online users under certain conditions.

As a result of generalization and selection of existing approaches we have substantiated multicriteria systematization of platforms (Fig. 3).

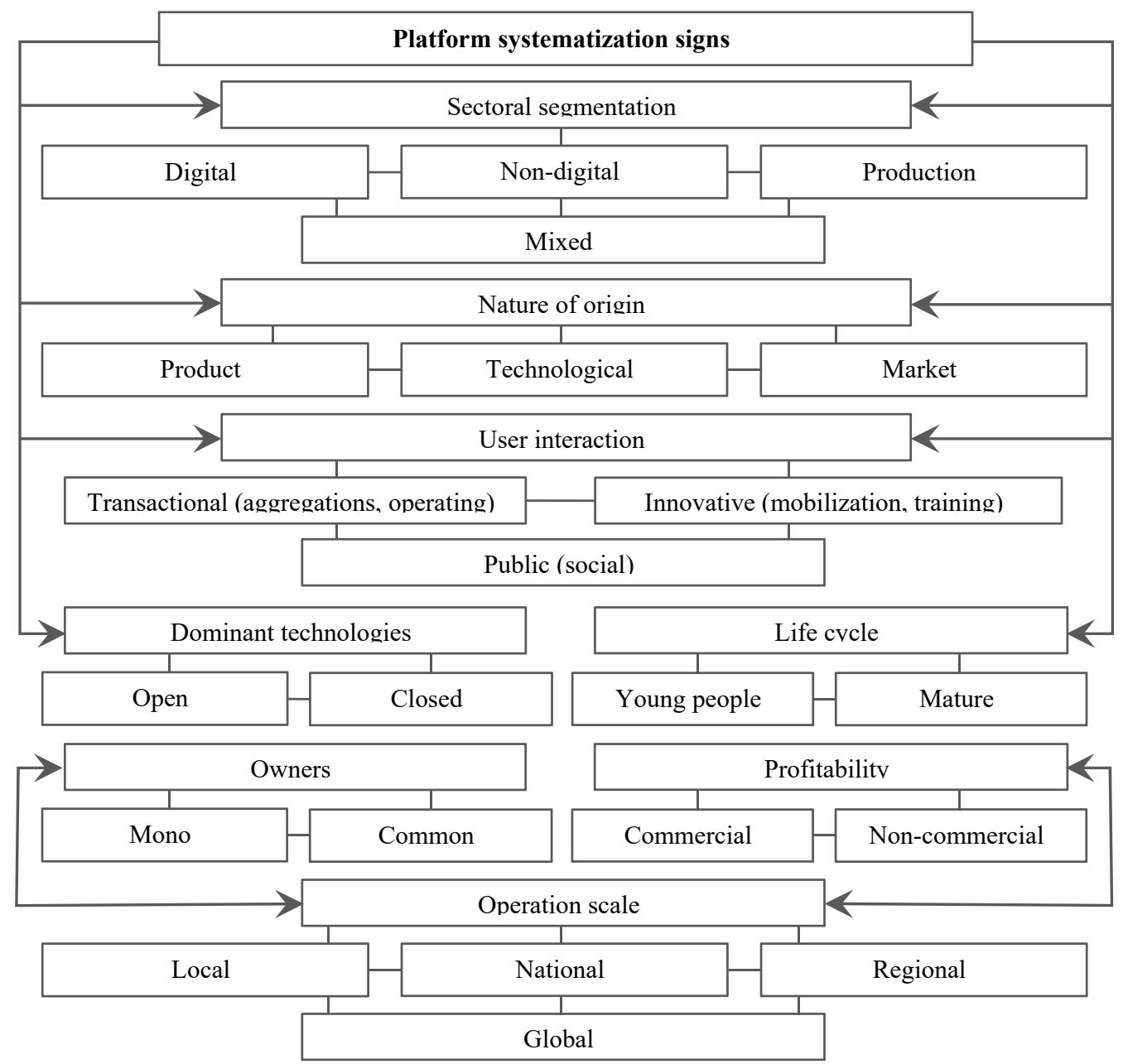

Fig. 3. Options for systematization of platforms 
It is significantly that it applies almost exclusively to digital platforms. Moreover, their further differentiation is obvious. Thus, on the basis of "profitability" it is possible to attribute the following ones to commercial platforms - social (Facebook, VK), educational (Courser, Lectorium), investment (Instant Success, OneRay) platforms, electronic payment systems (PayPal), direct e-commerce of goods and services (Ikea, Samsung), and trading platforms of intermediaries (AliExpress, Ebay); and it is possible to attribute to non-commercial platforms: charity (Planeta), platforms for exchange (Gilgamesh), platforms of free services (Couchsurfing), educational and information platforms (Wikipedia) ${ }^{34}$.

The highest platform activity is recorded in North America, Europe, Asia, Africa, and Latin America and is associated with the activities of such well-known companies as Amazon, Apple, Google and Alibaba. Nevertheless, along with large companies, smaller business platforms are developing from other parts of the world, such as Rakuten (Japan), Delivery Hero (Germany), Naspers (South Africa), Flipkart (India) or Javago (Nigeria) ${ }^{35}$ (Fig. 4)

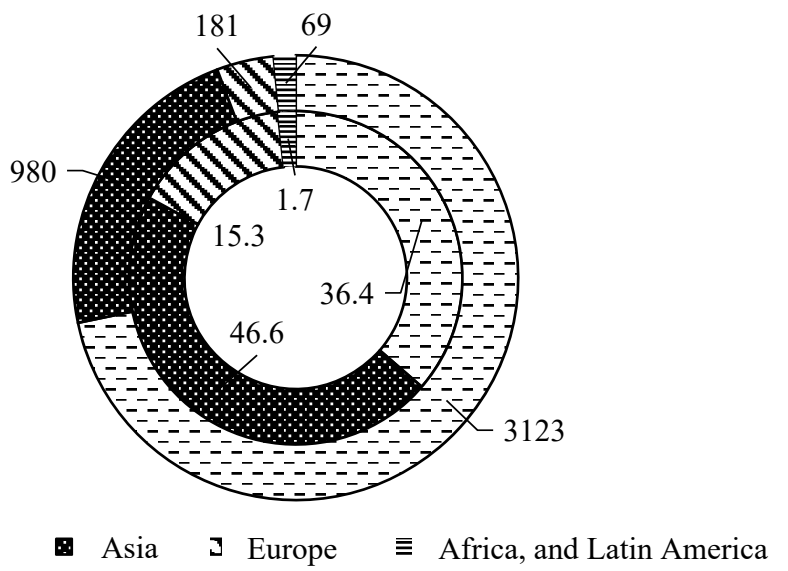

Small circle - number of platform companies, \%

Large circle - market capitalization of platform companies, billion USD

Fig. 4. Regional indicators of representation of the largest platforms of the global economy in $2015^{36}$

\footnotetext{
${ }^{34}$ Ibid. p. 1419.

${ }^{35}$ Evans, P. C., Gawer, A. The Rise of the Platform Enterprise: A Global Survev, The Center for Global Enterprise. 2016. URL: https://www.bearingpoint.com/files/Global_Platform_Survey_Jan_2016.pdf\&download= 0\&itemId=289645.

${ }^{36}$ Developed by the authors based on: Evans, P. C., Gawer, A. The Rise of the Platform Enterprise: A Global Survey, The Center for Global Enterprise. 2016. URL: https://www.bearingpoint.com/files/ Global_Platform_Survey_Jan_2016.pdf\&download=0\&itemId=289645.
} 
Identified platform companies represent a total of 22 countries. The largest number of platforms was recorded in China, USA, Great Britain and India (Fig. 5).

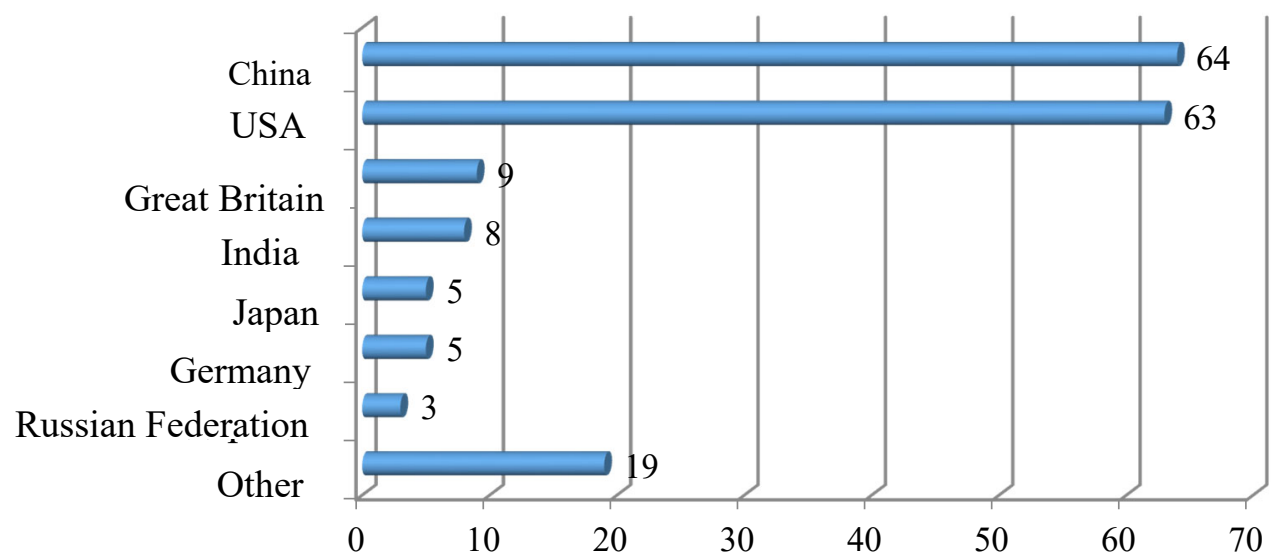

Fig. 5. National representation of platform companies in 2015, units ${ }^{37}$

The platform business is concentrated to the scale of individual cities or clusters: San Francisco Bay Area (44 platforms) in USA, Beijing (30) and Shanghai (15) in China.

It is worth noting that USA and China account for $75 \%$ of all patents related to blockchain technology, $50 \%$ of global spending on the Internet of things, more than $70 \%$ of open cloud computing technology. It is noteworthy that these countries account for $90 \%$ of the market capitalization of the 70 largest digital platforms in the world with a share of Europe being 4\%, Africa and Latin America $-1 \%{ }^{38}$.

Today, most researchers, including Evans P. C., Gawer A. rightly, in our opinion, distinguish both positive and possible negative impact of digital platform business on the global economy ${ }^{39}$. It is noted that the unconditional positive economic effect of the spread of the platform business model is the impact on the productivity growth dynamics, which is achieved in three main ways: application within the platform business of the method of more efficient use of assets in accordance with the principles of modularity, combinatorics and reusability;

\footnotetext{
37 Ibid.

${ }^{38}$ Digital Economy Report 2019. Value Creation Benefits: Implications for Developing Countries (rus. Doklad o tsifrovoy ekonomike 2019. Sozdanie stoimosti poluchenie vyigod: posledstviva dlya razvivavuschihsya stran) / UN Overview, 2019, UNCTAD. - 16 p. URL: https://unctad.org/en/PublicationsLibrary/der2019_overview_ru.pdf. [In Russian]. - p. 4.

${ }^{39}$ Evans P. C., Gawer A. The Rise of the Platform Enterprise: A Global Survey, The Center for Global Enterprise. 2016. URL: https://www.bearingpoint.com/files/Global_Platform_Survey_Jan_2016.pdf\&download=
} $0 \&$ itemId $=289645$. 
implementation of the requirements of personal compliance, wide variety and instant interaction; systematic production of innovations and organization of a specific environment conducive to further innovation around a platform model. Developing this approach, we assume that the innovation environment, which is gradually organized around the platform as it is developing in space and time, is a set of innovative "waves" of users (application developers and end users) with different degrees of modification and use of basic platform technologies. There are formed innovative infrastructure and innovative services in this environment in accordance with the tasks of effective production of innovations and all new points of probable communication between users of a platform arise. For the second wave of users, these will be platform innovations with aggregate personal matching and multiplier use of assets. With each innovative wave of users, the global positive effect will grow, and scientific and technological progress will contribute to the continuity of progress, the formation of new generations of platforms.

Typically, platforms provide the ability to use specific solutions, related services, advertising support, etc. without the need to independently develop or acquire the appropriate patents ${ }^{40}$. At the same time, the transformations caused by the spread of the platform business model, which have an ambiguous assessment on the scale of positivity ${ }^{41}$, include the complexity of compliance with intellectual property rights, antitrust law, the use of institutional and competitive regulation.

In a broader context, inter-corporate, inter-country and inter-regional contradictions and asymmetries are associated with the establishment of global digital platforms.

\section{Development of platform business models}

Global catalysts (digital technologies expansion, radical changes in consumer mentality, macroeconomic dependencies, government policies), rapid capitalization of technology companies and systematic growth of their productivity since the mid-2000s are associated by the scientific community and business representatives with the formation of the platform business models and platform company phenomenon ${ }^{42}$. Today, actively growing in scale and scope platform business model is inherent not only to social networks, travel, books, music, but also to the

\footnotetext{
${ }^{40}$ Platform economy / Wikipedia. URL: https://ru.wikipedia.org/. [In Russian].

41 Evans P. C. Gawer A. The Rise of the Platform Enterprise: A Global Survey, The Center for Global Enterprise. 2016. URL: https://www.bearingpoint.com/files/Global_Platform_Survey_Jan_2016.pdf\&download=

$0 \&$ itemId $=289645$.
42 Ibid.
} 
production of software, transport and banking services, health care, energy, public administration, etc.

The driver of the formation and development of the platform business model was the revolutionary changes in digital technologies in the XXI century, when data began play the key role in relations with employees, customers and other business representatives. N. Srnychek connects the appearance of a new business model - a platform with its ability "A new business model has appeared - a platform that is able to isolate and control a huge amount of data ${ }^{43}$. The vast majority of digital goods are produced and consumed on the basis of digital platform business models that provide for the availability of an appropriate online environment ${ }^{44}$. A separate section is devoted to global digital platforms and business models in the UN report on the digital economy in $2019^{45}$.

Typically, digital platforms offer comprehensive standard solutions for interaction between users as their top priority ${ }^{46}$. Extraordinary attention to the interests of each party with the provision of its own profitability is the basis of the business model of platforms in industries that operate using external networks and network effects (software, portals and media, payment systems and the Internet). Expanding the format of interaction from bilateral "developer - consumer" to multilateral "developer - platform - consumer" format encourages the platform to pursue a policy of structured profit in relations with developers and end users, which has sectoral peculiarities: video game platforms (Sony, Sega, etc.) provide their income mainly in the form of royalties, operating system platforms for personal and portable computers (Windows, MacOS, Unix/Linux, Android) - through profits from end users, and platforms of open electronic publications, travel organizations, online dating get their profit only through interaction with one segment of users, which is considered to be subsidizing for another ${ }^{47}$ (Fig. 6).

Thus, depending on the chosen business model, one of the user groups is considered by the platform to be "profit center" (profit-making segment,

${ }^{43}$ Srnychek N. Platform Capitalism (rus. Kapitalizm platform) [Text] / transl. from English and sc. ed. By M. Dobryakova; National Research University "Higher School of Economics" (rus. Nats. issled. un-t "Vyisshaya shkola ekonomiki"). Moscow: Ed. House of the Higher School of Economics, 2019. - 128 p. [In Russian].

${ }^{44}$ Antipina O. N. How much is a digit worth? On the nature of the price of goods in the digital economy (rus. Skolko stoit tsifra? O prirode tsenyi blag $\mathrm{v}$ tsifrovoy ekonomike). Social sciences and modernity (rus. Obschestvennyie nauki i sovremennost). 2019, No. 5. - pp. 5-16. [In Russian]. - p. 9.

${ }^{45}$ Digital Economy Report 2019. Value Creation Benefits: Implications for Developing Countries (rus. Doklad o tsifrovoy ekonomike 2019. Sozdanie stoimosti poluchenie vvigod: posledstviva dlya razvivavuschihsva stran) / UN Overview, 2019, UNCTAD. - 16 p. URL: https://unctad.org/en/PublicationsLibrary/der2019_overview_ru.pdf. [In Russian].

${ }_{46}$ Rochet, J.-C., Tirole, J. Platform Competition in Two-Sided Markets. Journal of the European Economic

Association. 2003, No. 1 (4), P. 990-1029 URL: https://www.rchss.sinica.edu.tw/cibs/pdf/RochetTirole3.pdf.
47 Ibid. 
subsidizing segment), and the other is considered to be a "loss leader" or "financially neutral" (break- even segment, subsidized segment) ${ }^{48}$.

An acute issue of the platform business is the settlement of the interests of platform owners, developers of additional services based on the platform and ordinary users ${ }^{49}$. Thus, Hagel J. notes that the owners of the platform are usually in the so-called "Point of influence", which is characterized by privileged access to a wider and more diverse flow of knowledge, and therefore allows to more accurately predict potential changes in the market and, accordingly, timely adjust market strategy to maximize operational and financial leverage. At the same time, companies that do not own the platform, but are woven into its structure, feel the risk of not receiving the added value that was created by them and therefore, they are directly interested in close contact with the owners ${ }^{50}$.

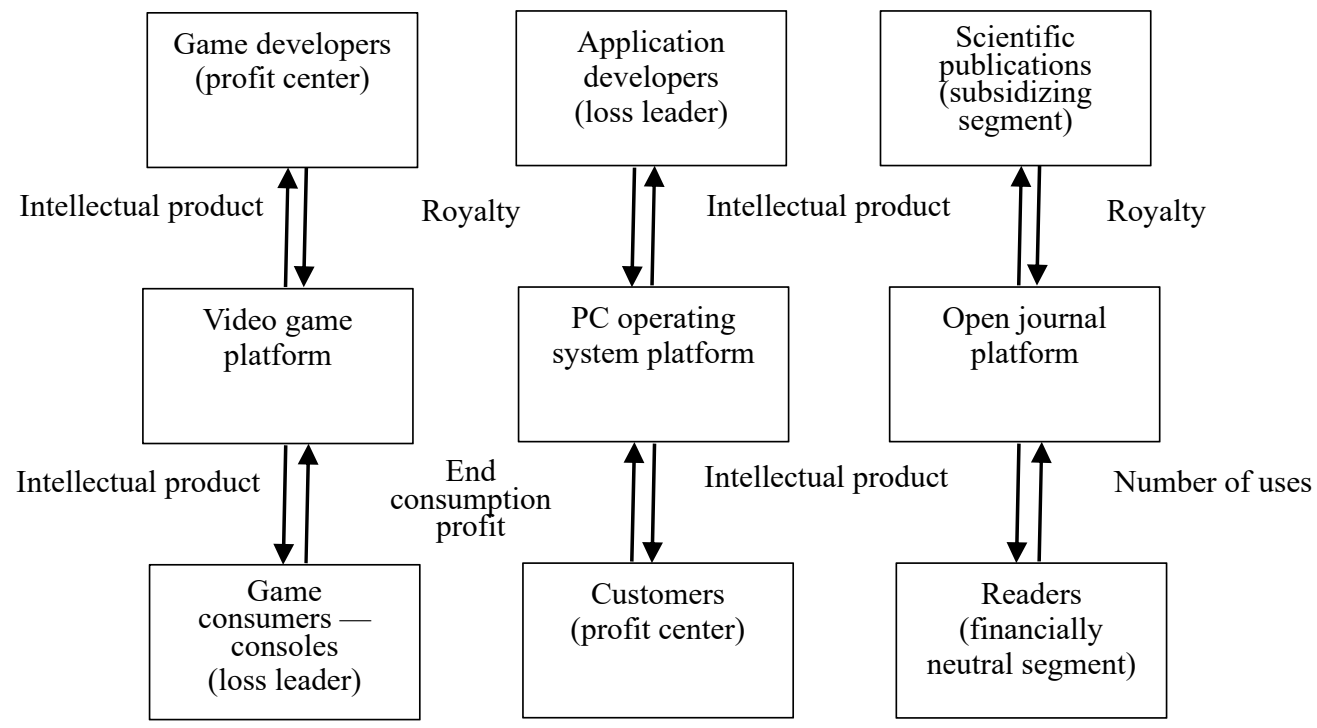

Fig. 6. Sectoral features of the platform business model formation ${ }^{51}$

\footnotetext{
${ }^{48}$ Ibid.

${ }^{49}$ Hagel, J. The power of platforms. Part of the Business Trends series. Deloitte Development LLC. 2015. URL: https://www2.deloitte.com/us/en/insights/focus/business-trends/2015/platform-strategy-new-level-businesstrends.html; Baldwin C. Y., Woodard C. J. The Architecture of Platforms: A Unified View / Platforms, Markets and Innovation, Cheltenham, UK - Northampton, US: Edward Elgar Publishing Limited \& Edward Elgar Publishing, Inc. 2009. URL: https://www.elgaronline.com/view/9781848440708.xml doi: 10.4337/9781849803311.00002; Sawhney, M. S. Leveraged High-Variety Strategies: From Portfolio Thinking to Platform Thinking. Journal of the Academy of Marketing Science. 1998. Vol. 26, No.1. - p. 54-61. URL: https://www.researchgate.net/ publication/226750238_Leveraged_High-Variety_Strategies_From_Portfolio_Thinking_to_Platform_Thinking.

${ }^{50}$ Hagel J. The power of platforms. Part of the Business Trends series. Deloitte Development LLC. 2015. URL: https://www2.deloitte.com/us/en/insights/focus/business-trends/2015/platform-strategy-new-level-businesstrends.html

${ }_{51}$ Developed by the authors based on: Rochet J.-C., Tirole J. Platform Competition in Two-Sided Markets. Journal of the European Economic Association. 2003, No. 1 (4), P. 990-1029 URL:
} https://www.rchss.sinica.edu.tw/cibs/pdf/RochetTirole3.pdf. 
Mistakes of platform owners regarding the time of admission of additional services to the basic technology are strategic, as they directly affect the profitability of the platform in the future. Once, when IBM created PC platform, it entrusted outsourcing of the development of the operating system and central processing unit to Microsoft and Intel respectively, because it did not perceive them as the main technologies of the platform ${ }^{52}$. As a result, the business of each of these companies is now identified as platform. Baldwin C. and Woodard C. J. note that the tendency of platform owners to turn to developers of add-ons (or complements) is directly influenced by the following factors: homogeneity and predictability of consumer preferences, adequacy of intellectual potential and investment capital of the platform base, the need to establish fast links with numerous developers of add-ons (such as eBay transactions, payment card service, Google search service) ${ }^{53}$. Recognizing the importance of the company's strategic focus on creation of a "product" or "industry" platform, A.Gawer and M. Cusumano ${ }^{54}$ point out the main difference between these strategies: greater control of the product platform by its owner due to intellectual property rights and the growing interdependence of a wide range of participants in the industry platform (owners, additional services, users) while weakening property relations and formation of a platform business "ecosystem".

The basis of the fundamental architecture of the platform is the division of components into modules depending on the functions performed, and the economic effect is the achievement of activity scale economies $^{55}$. The division of platform components into modules is based on their diversity and probability of reuse. Accordingly, in the architecture of the platform, it is possible to distinguish the "basis", characterized by low diversity, relatively stable interactions and high probability of reuse, and "peripherals" - modules of high diversity with situational interactions and low probability of reuse. These "basis" and "periphery" characteristics are determined by their functions: "Basis" performs the function of preserving the main product, technology, method of interaction in the market, which reflects the nature of a

\footnotetext{
52 Sawhney M. S. Leveraged High-Variety Strategies: From Portfolio Thinking to Platform Thinking. Journal of the Academy of Marketing Science. 1998. Vol. 26, No. 1. P. 54-61. URL: https://www.researchgate.net/publication/226750238_Leveraged_High-Variety_ Strategies_From_Portfolio_Thinking_to_Platform_Thinking.

${ }_{53}$ Baldwin $\bar{C}$. Y., Woodard C. J. The Architecture of Platforms: A Unified View / Platforms, Markets and Innovation, Cheltenham, UK - Northampton, US: Edward Elgar Publishing Limited \& Edward Elgar Publishing, Inc. 2009. URL: https://www.elgaronline.com/view/9781848440708.xml doi: 10.4337/9781849803311.00002

${ }^{54}$ Gawer A., Cusumano M. A. Strategies for Platform-Leader Wannabes, Prepared for the IIPS Symposium on Globalization and Japan's Science and Technology Strategy. 19-20 November 2007, Tokyo. URL: http://www.iips.org/publications/data/07techGawer.pdf.

55 Baldwin C. Y., Woodard C. J. The Architecture of Platforms: A Unified View / Platforms, Markets and Innovation, Cheltenham, UK - Northampton, US: Edward Elgar Publishing Limited \& Edward Elgar Publishing, Inc. 2009. URL: https://www.elgaronline.com/view/9781848440708.xml doi: 10.4337/9781849803311.00002
} 
particular platform, and "periphery" performs the function of evolution, rapid development, progress by controlling the addition, removal, recombination of components. The system interaction of these groups of components is focused on fluctuations in demand in the markets of the product, and therefore, it is focused on the preferences of users of the platform. The coordination of "basic" functions and "peripheral" development with the parameters of demand determines the proposal of numerous applications from the platform and bringing them to market, which contributes to the appearance of "probable coupling points".

A feature of the platform economy, in our opinion, is the presence of both commercial interaction (i.e. on a paid basis) and free interaction, the subject of which is a certain "open source". Despite the low profitability or no revenue at all from a certain segment of users, the platform is not interested in their reduction or abandonment of segments, as only the presence of complementary user parties is the foundation of its business. Thus, developers are interested in consumers and consumers are interested in developers, and the platform offers effective solutions for their interaction. The competition among the platforms is also special, as users and their segments can migrate freely, significantly affecting the profitability of the business. The interest of the platform in users is explained not only by the actual profitability of segments, but also by potential non-financial effects, which, ultimately, affect the profitability indicators (Fig. 7).

For example, developers of applications for operating systems are interested in production of a guaranteed quality product that will be in demand in the market, for which they provide information about the future product on a free basis to customers and open access to its testing on a particular platform or platforms. In this way, customers can assess their own need for the announced product and at the same time identify certain defects that prevent its effective use. As a result, developers receive feedback from customers, based on which the product is improved before its commercial launch. In this process, there are important the conditions under which the platform allows developers to conduct marketing research, testing, self-promotion and dissemination of philanthropic ideas, solutions and allows customers to have access to this information. Normally, the following dilemma is to be solved: choosing the product first and then the platform that ensures its effective use, or choosing the platform first and then the product, the use of which is provided by it. Such roles of a platform in interaction with users cause the appearance of the following effects: cumulative effect, which provides an expansion of the user base due to the accumulated experience of effective solutions, affects the speed of platform interaction and realization of user interests; compatibility (or 
cross-platform) effect, which increases the attractiveness of the platform by expanding the base of products offered by the platform.

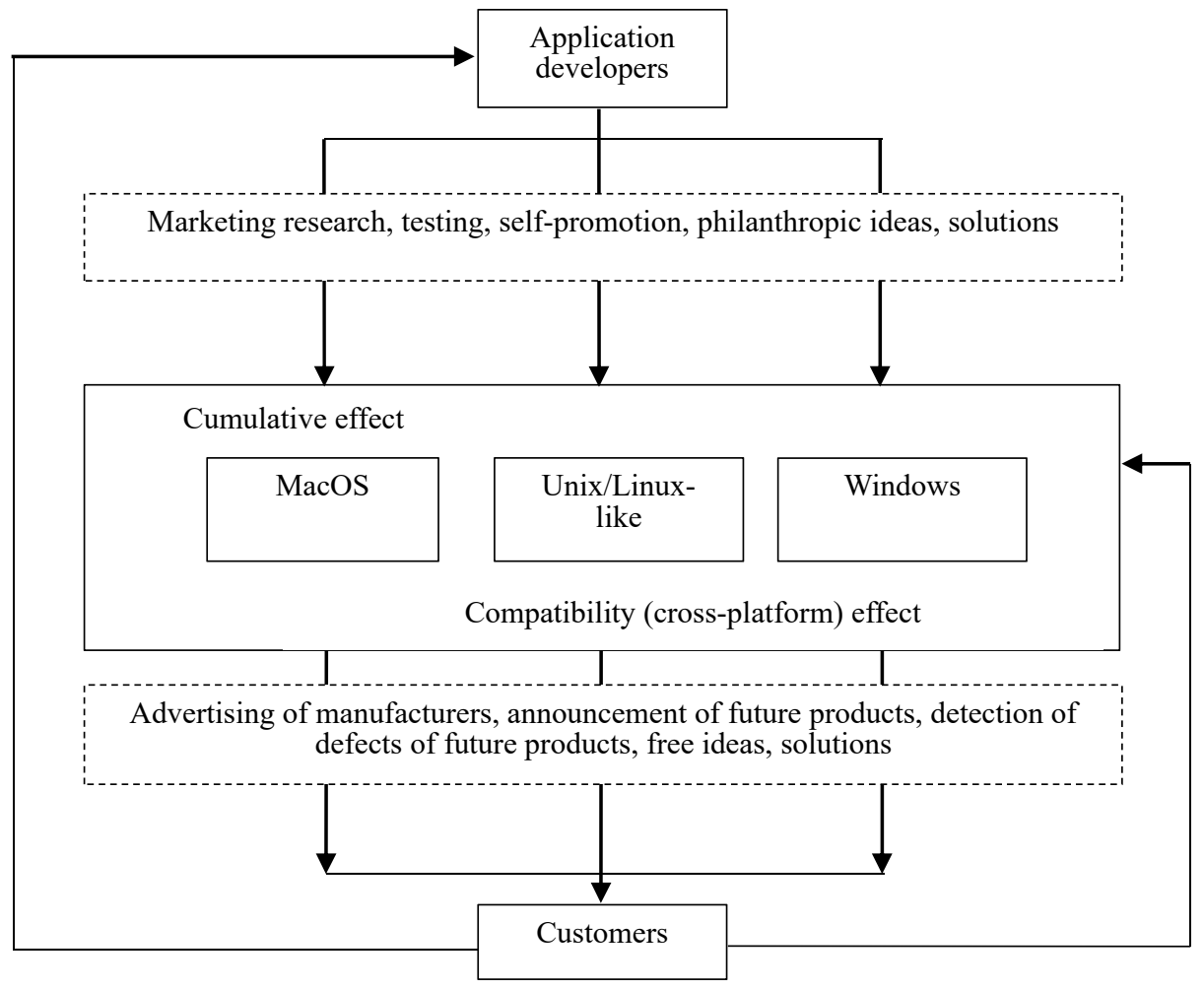

Fig. 7. Non-financial effects in the business model of the operating system platform for $\mathrm{PC}^{56}$

In the process of role optimization in the formation of financial and non-financial effects of the platform business model, in our opinion, the competitive advantages of inter-platform competition are generated, primarily related to the motives of user migration. In the concept of the platform as a management system, it can be considered the basis for achievement of the easiest access, interaction between participants and resources of business ecosystems ${ }^{57}$. The effect is achieved through structural management positioning (considering who and how can participate in the interaction to avoid possible disputes). A set of

\footnotetext{
${ }^{56}$ Developed by the authors.

${ }^{57}$ Hagel, J. The power of platforms. Part of the Business Trends series. Deloitte Development LLC. 2015. URL: https://www2.deloitte.com/us/en/insights/focus/business-trends/2015/platform-strategy-new-level-business-
} trends.html 
protocols is developed to facilitate communication, coordination and interaction. Hagel J. emphasizes that platforms are increasingly relying on a digital infrastructure that promotes interaction and collaboration, while being a desirable but not a prerequisite for platform formation.

Digital platform business is characterized by high-speed evolution: from simple one-dimensional SaaS (Software as a Service) models to PaaS (Platform as a Service) and multi-level IaaS (Infrastructure as a Service) models in the early 2000s, and to network platforms SoSA (System-of-System Architecture) in the mid-2000s ${ }^{58}$. It is significant that the representatives of the IT business believe that the digital interaction of companies is becoming more important than the digital system of the company $^{59}$.

In the first stage of digital business platforming, in the absence of barriers to entry into the IT industry, the share of small market participants increased ${ }^{60}$. For example, the number of Google employees was about 60 thousand people, and Facebook - 12 thousand people. WhatsApp employed only 55 people when Facebook bought it for USD 19 billion, and Instagram employed 13 people when it was bought for USD 1 billion ${ }^{61}$. Despite their small size, the products of technology companies were fast-spreading (and if it took the radio 38 years to reach a user base of 50 million people, the popular mobile game Angry Birds reached this figure in 35 days $^{62}$ ) and had high performance (45 million people per month use LinkedIn for searching, and in the 2000s every 5th smartphone supported NFC - "one-touch" technology) ${ }^{63}$.

Later, global digital platforms - corporations (Google, Facebook, Amazon, Alibaba, etc.) began to emerge and tend to monopolize markets. They implement their expansionist strategies through unprecedented R\&D investment, mergers and acquisitions, partnerships and alliances, and lobbying at the national and international political levels. In this context, experts emphasize the threat that countries,

${ }^{58}$ Rozanova N. Evolution of the Firm in the Digital Economy (rus. Evolyutsiya firmyi v usloviyah tsifrovoy ekonomiki). World economy and international relations (rus. Mirovaya ekonomika i mezhdunarodnyie otnosheniya). 2019. - T. 63. No.8. - pp. 21-28. [In Russian].

59 Kane, G.C., Palmer, D., Phillips, A.N., Kiron, D., Buckley, N. Strategy, not Technology, Drives Digital Transformation: Becoming a Digitally Mature Enterprise. MIT Sloan Management Reveiew. 2015, July. - pp. 1-29.

${ }^{60}$ Deloitte Development LLC. Patterns of disruption: anticipating disruptive strategies in a world of unicorns, black swans, and exponentials. Bratislava: Deloitte University Press. 2015. https:/www2.deloitte.com/content/dam/Deloitte/nl/Documents/technology/deloitte-nl-deloitte-patterns-ofdisruption.pdf

${ }^{6}$ Srnychek N. Platform Capitalism (rus. Kapitalizm platform) [Text] / transl. from English and sc. ed. By M. Dobryakova; National Research University "Higher School of Economics" (rus. Nats. issled. un-t "Vyisshaya shkola ekonomiki"). Moscow: Ed. House of the Higher School of Economics, 2019. - 128 p. - p. 10. [In Russian].

${ }^{6}$ Deloitte Development LLC. Patterns of disruption: anticipating disruptive strategies in a world of unicorns, black swans, and exponentials. Bratislava: Deloitte University Press. 2015.2 URL: https:/www2.deloitte.com/content/dam/Deloitte/nl/Documents/technology/deloitte-nl-deloitte-patterns-ofdisruption.pdf

${ }^{63}$ Leger B. Fresh Mobile Trends. Upland Localytics. URL: http://info.localytics.com/blog/mobile-statistics 
regardless of their level of development, will become raw data providers for global digital platforms, paying for the "digital intelligence" of their owners ${ }^{64}$.

\section{Conclusions}

In the process of expansion and deepening of global informatization, the industrial revolution 4.0 started at the beginning of the XXI century. Based primarily on digital technologies, it has led to the fundamental qualitative changes in virtually all areas of business and market segments, government regulation and public life. Business processes and models are rapidly transforming, acquiring mainly platform features in the global networked digital space.

The reaction of economics to the latest phenomena of superdynamic practice can be seen in the essential characteristics of platforms and their systematization, research of platform companies, their strategies and management. Platform business models operating in the relevant online environment are the most effective in the process of evolution of companies and their digital transformation.

The terms "platform economy" and "platform thinking" are becoming familiar and well-defined in academic environment. At the same time, the process of terminological identification is becoming permanent. Thus, such new concepts as "digital capital" and "platform capital" need to be understood in the global political economy, which will contribute to the fundamentalization of research in modern economic micro- and macro-systems.

Systemic measures to respond to qualitative changes in the labor market are acute, primarily related to the introduction of artificial intelligence technologies, which will be accompanied by mass layoffs, disappearance of hundreds of traditional professions, transformation of jobs, offices, working hours and more. Under such conditions, universal access to constantly updating educational platforms becomes important, and research interest will increasingly shift to the "economics of artificial intelligence", "longevity economics", "health economics", and "leisure economics".

\section{References}

1. Antipina O. N. How much is a digit worth? On the nature of the price of goods in the digital economy (rus. Skolko stoit tsifra? O prirode tsenyi blag v

\footnotetext{
${ }^{64}$ Digital Economy Report 2019. Value Creation Benefits: Implications for Developing Countries (rus. Doklad o tsifrovoy ekonomike 2019. Sozdanie stoimosti poluchenie vyigod: posledstviya dlya razvivayuschihsya stran) / UN Overview, 2019, UNCTAD. - 16 p. URL: https://unctad.org/en/PublicationsLibrary/der2019_overview_ru.pdf. [In Russian]. - p.10.
} 
tsifrovoy ekonomike). Social sciences and modernity (rus. Obschestvennyie nauki $i$ sovremennost). 2019, No. 5. - pp. 5-16. [In Russian].

2. Armstrong, M. Competition in Two-Sided Markets. The RAND Journal of Economics. 2006, Vol. 37, No. 3. - pp. 668-691.

3. Bresnahan, T.F. and Greenstein, S. Technological competition and the structure of the computer industry. Journal of Industrial Economics, 1999. 47 (1). - pp. 1-40. URL: http://www-siepr.stanford.edu/workp/swp97028.pdf

4. Baldwin, C. Y. and Woodard, C. J. The Architecture of Platforms: A Unified View / Platforms, Markets and Innovation. The Architecture of Platforms: 2009, Cheltenham, UK and Northampton, US: Edward Elgar. URL: https: / /www.elgaronline.com/view /9781848440708.xml

5. Deloitte Development LLC. Patterns of disruption: anticipating disruptive strategies in a world of unicorns, black swans, and exponentials. Bratislava: Deloitte University Press. 2015. URL: https://www2.deloitte.com/ content/dam/Deloitte/nl/Documents / technology/deloitte-nl-deloitte-patternsof-disruption.pdf

6. Digital Economy Report 2019. Value Creation Benefits: Implications for Developing Countries (rus. Doklad o tsifrovoy ekonomike 2019. Sozdanie stoimosti poluchenie vyigod: posledstviya dlya razvivayuschihsya stran) / UN Overview, 2019, UNCTAD. - 16 p. URL: https://unctad.org/ en/PublicationsLibrary/der2019_overview_ru.pdf. [In Russian].

7. Evans, P. C., Gawer, A. The Rise of the Platform Enterprise: A Global Survey. The Center for Global Enterprise. 2016. URL: https://www.bearingpoint.com/files /Global_Platform_Survey_Jan_2016.pdf\&d ownload $=0$ \&itemId $=289645$;

8. Gawer, A. and Cusumano, M.A. Platform Leadership: How Intel, Microsoft, and Cisco Drive Industry Innovation, Boston, MA: Harvard Business School Press. 2002. http: / / platformleadership.com / articles / Case\%20Folio.pdf

9. Gawer A., Cusumano M. A. Strategies for Platform-Leader Wannabes, Prepared for the IIPS Symposium on Globalization and Japan's Science and Technology Strategy. 19-20 November 2007, Tokyo. URL: http: / / www.iips.org / publications / data /07techGawer.pdf.

10. Gawer, A., Cusumano, M. A. Industry Platforms and Ecosystem Innovation. J Prod Innov Manaq 31. September 4, 2013, No. 3. - pp. 417-433. URL: https://dspace.mit.edu/bitstream/handle/1721.1/98590/Cusumano_ Industry\%20platforms.pdf? sequence $=1 \&$ isAllowed $=y$.

11. Gawer A. Bridging differing perspectives on technological platforms: Toward an integrative framework. Research Policy. 2014, Vol.43. - pp. $1239-$ 1249 URL: https://reader.elsevier.com/reader/sd/pii / S0048733314000456?token=E6A6AB71472790461F89059913D1BF85632768A200F3 4D88A02C53F602FBFEC4E9990A5038925D1F3275DB04BEFB58FB.

12. Hagel, J. The power of platforms. Part of the Business Trends series. Deloitte Development LLC. 2015. URL: https://www2.deloitte.com/ us / en /insights / focus / business-trends / 2015 / platform-strategy-new-levelbusiness-trends.html. 
13. Hagiu, A. Pricing and Commitment by Two-Sided Platforms. The RAND Journal of Economics. 2006, Vol. 37, No. 3. -pp. 720-737.

14. Hagiu, A. \& Wright, J. Multi-Sided Platforms. Harvard Business School March. 2015. URL: http://www.hbs.edu/faculty/Publication\%20Files/15037 cb5afe51-6150-4be9-ace2-39c6a8ace6d4.pdf

15. Kane, G.C., Palmer, D., Phillips, A.N., Kiron, D., Buckley, N. Strategy, not Technology, Drives Digital Transformation: Becoming a Digitally Mature Enterprise. MIT Sloan Management Reveiew. 2015, July. - pp. 1-29.

16. Kim D.-J. \& Kogut B. Technological Platforms and Diversification. Organization Science. 1996. Vol. 7, No. 3. URL: https: / / www0.gsb.columbia.edu /faculty / bkogut /files /1996_OrgSci_Kim_Kog ut.pdf

17. Khaustov, V. Digital Economy: How Do You Serve? (rus. Tsifrovaya ekonomika: kak tebe sluzhitsya?). ZN.UA. 2019, No. 39. URL: https: / / zn.ua/macrolevel/cifrovaya-ekonomika-kak-tebe-sluzhitsya-

333086 .html.[In Russian].

18. Kogut B. \& Kulatilaka N. Options Thinking and Platform Investments: Investing in Opportunity. California Management Review. 1994. Vol. 36, No. 2. - pp. 52 -71. URL: https:/ / www.researchgate.net/publication/239066520 Options_Thinking_and_Platform_Investments_Investing_in_Opportunity

19. Leger, B. Fresh Mobile Trends. Upland Localytics. URL: http:/ /info.localytics.com/blog/mobile-statistics.

20. Oleinikova Yu.A. Challenges and business development models in the context of progress (rus. Vyizovyi i modeli razvitiya biznesa $\mathrm{v}$ usloviyah progressa). Innovative Economy Issues (rus. Voprosyi innovatsionnoy ekonomiki). 2019. No. 4. [In Russian]. - p. 1418.

21. Platform economy / Wikipedia. URL: https://ru.wikipedia.org/. [In Russian].

22. Rochet, J.-Ch. ; Tirole, J. Platform Competition in Two-Sided Markets. Journal of the European Economic Association. 2003. T. 1, No. 4. - pp. 9901029. URL: https: / / www.rchss.sinica.edu.tw / cibs / pdf / RochetTirole3.pdf

23. Rochet J.-C., Tirole J. Two-Sided Markets: a progress report. The RAND Journal of Economics. 2006, Vol. 37, No. 3. P. 645-667.

24. Rozanova N. Evolution of the Firm in the Digital Economy (rus. Evolyutsiya firmyi $\mathrm{v}$ usloviyah tsifrovoy ekonomiki). World economy and international relations (rus. Mirovaya ekonomika i mezhdunarodnyie otnosheniya). 2019. - T. 63. No.8. - pp. 21-28. [In Russian].

25. Rysman, M. The Economist of Two-Sided Markets. Journal of Economic Perspectives. 20069, Vol. 23, No. 3. - pp. 125-143.

26. Sawhney, M. S. Leveraged High-Variety Strategies: From Portfolio Thinking to Platform Thinking. Journal of the Academy of Marketing Science. 1998. Vol. 26, No.1. - p. 54-61. URL: https://www.researchgate.net/ publication/226750238_Leveraged_High-

Variety_Strategies_From_Portfolio_Thinking_to_Platform_Thinking.

27. Turn products into product platforms Providing a foundation for others to build upon. URL: https://www2.deloitte.com/content/dam/insights/us / 
articles / disruptive-strategy-product-platforms / DUP_3056_Products-toplatforms_v2.pdf

28. Wheelwright, S. C. \& Clark, K. B. Creating Project Plans to Focus Product Development. Harvard Business Review. From the March-April 1992. Issue 70. URL: https: / / hbr.org $/ 1992 / 03 /$ creating-project-plans-to-focusproduct-development

The article was received by the Editorial Board on April 23, 2020. 